\title{
Political and Legal Concept of Modern Democratic State
}

\author{
Yuliy A. Nis nevich \\ National Research University «Higher School of Economics», People's Friendship University of Russia Moscow, Russia
}

\begin{abstract}
The paper proposes a political and legal approach to conceptualizing modern democratic state as law-governed, social and secular. It defines legal, institutional, and socio-political characteristics of law-governed, social, and secular state.
\end{abstract}

Keywords Legal And Political Concept, State, Law-Governed, Social, Secular

\section{Introduction}

Law-governed state is generally acknowledged to be the basic politico-juridical form of democratic state in the 21th century. It seems feasible to define the essence of the law-governed state in the following manner. In a law -governed, it is law, impartial and tolerant to different world-views and convictions, that is a universal regulator of social relations, whose purpose is stabilization of the entire social space. Law also has a definitive influence on such a specific sphere of social life as politics, which, along with law, is a universal regulator of that segment of social relations which is concerned with competitive relations and interactions among individuals and groups in order to obtain, keep, and utilize state power. It is law that defines the system of values and regulations of the representative poliarchy as a modern form of political and governmental organizat ion and its basic, according to Robert Dahl[1], "political institutions ".

Diss emination of social rights as a type of human rights in the $20^{\text {th }}$ century fostered democratic state of law to transform into social state. Social state can be defined in general terms as such an organization of state order which is aimed at guaranteeing the population its social rights and compels the state to protect those rights.

Furthermore, the secular character of the state is one of the basic principles of the law-governed state functioning and development within national models. In the judicial context, secular state is such an organization of state order that is specifically aimed at observance and protection of freedom of thought, conscience, and religion as well as other convictions, including non-religious ones, as stated in a binding form by article 18 of the General Pact of Civil and Political Rights, i.e. at an actualization of the principle of state's nonintervention and tolerance towards different

* Corresponding author:

nisjulius@gmail.com (Yuliy A. Nisnevich)

Published online at http://journal.sapub.org/sociology

Copyright (C) 2012 Scientific \& Academic Publishing. All Rights Reserved religious and non-religious worldviews and convictions.

\section{Objectives}

Objectives of the present research consist in political and legal interpretation and conceptualization of modern democratic state as law-governed, social and secular. As there is no general consensus about a corresponding politico-juridical form of the state, this will be described with a set of basic political institutions, key social relations and values.

\section{Methods}

Methodologically the research is based on the new institutional approach which emphasizes institutional environment, fundamental political, social and juridical institutions, norms, relations and values. The basic tool of institutional analysis is politico-law analysis[2], which is a result of the development of the classical institutional method in contemporary world. Furthermore, behavioral analysis based on historical-cultural and contextual analysis used to identify social relations and values crucial for the modern democratic state.

\section{Concept of Modern Democratic State}

\subsection{Law-Governed State}

The key indication of a law-governed state is the acknowledgement of human being, their rights and freedoms as basically defined by the Universal Declaration of Human Rights, as a superior social value. From formal and legal standpoint, the only states that can lay claim to the status of law-governed state are the sovereign UN member states that participate in international pacts pertaining to civil, political, economic, social, and cultural rights. That is to say, these are the states that have taken upon themselves the responsibility of implementing the standards of international law as defined 
by those International acts. Such states constitute a vast majority among the sovereign UN members (more than $85 \%$ ). It must be stated, however, that nominal and legal participation in the international pacts does not necessarily mean that in all those states human and civil rights are in fact observed and defended or that the state really aspires to be a law-governed one.

Several principles are fundamental for the whole system of human rights and freedoms. They are the principle of equality as equality of rights and freedoms for every individual expressed also in his/her suprastate (exterritorial) status; the principle of interconditionality of human rights and freedoms in society; the principle of state's nonintervention into the individual's internal world and of tolerance towards different opinions and convictions.

The principle of interconditionality means that human rights and freedo $m s$ are inseparable fro $m$ the system of social relations and should be considered only within the framework of those relations. They do not contradict or depreciate requirements of morality or public order in a democratic state, in spite of the libelous claims by the opponents of human rights institute who consciously pass over in silence article 29 of the Universal Declaration of Human Rights and maintain that this institute causes "permissiveness". The possession of human rights and freedoms does not mean that their use or abuse create opportunities for unlimited lawlessness[3]. Each individual only possesses their own rights and freedoms inasmuch as they do not violate those of other people's. The principle of interconditionality defines the necessity to respect and observe other people's rights and freedoms in order to possess one's own.

The key rights that define the principle of nonintervention and tolerance are freedom of thought, conscience and religion and freedom of convictions and their expression, as stated by Articles 18 and 19 of the Universal Declaration of Human Rights. Critical for those covenants are, on the one hand, the prohibition of coercion to infringe on anyone's freedom of conviction and religion and, on the other hand, the possibility for a legal limitation of the same freedom according to the principle of interconditionality for the sake of protecting rights and freedoms of others.

In a law-governed state, considering irreducibility of Law to the system of laws, what acts as the system-creating factor in social regulation and political and governmental administration is the principle rule of law, albeit not in its classical, but a modern interpretation.

According to Albert Dicey's classical definition, the rule of law is primarily the absolute authority and superiority of existing legislation as opposed to arbitrary government prescriptions. This principle excludes not only governmental arbitrariness but als o the possibility for the govern ment to act at will, as situation requires[4]. According to the modern interpretation, the rule of law is primarily the absolute authority and superiority, in all spheres of life, of human rights and freedoms as vested in the Universal Declaration of Human Rights and international statutory acts, as well as in the current state legis lation. The very legitimacy of the state is legally based on the ensuring of rights and freedoms of its citizens as opposed to arbitrary orders by the authorities. Besides, equality of all in the face of law and justice is inherent in the rule of law principle.

This princip le defines the hierarchical system of priorities in law and legislature in the life of society and the state. Firstly, human rights and freedoms have absolute priority and superiority in the regulation of social relations. No national legislation, even passed in a full accordance with democratic procedures, may violate the freedoms guaranteed by the Universal Declaration of Human Rights and other international statutory acts, as well as generally accepted principles and rules of international law. Secondly, the state, including all its institutions, agencies, and officials, as well as citizens and their independent associations, must act strictly within the framework of the Constitution and legislation, which, in turn, must be based on human and civil rights and freedoms.

From the institutional standpoint, the generally acknowle dged indication of law-governed state is separation of judicial, leg is lative and executive powers, which from the outset has aimed at a prevention of monopolization of power or its usurpation by an individual or a group.

Today, in a postindustrial world, along with the classic principle of separation of powers, what distinguishes law-go verned state is a stable tendency to deepen government decentralization functionally and hierarchically, to separate its powers according to functions and competences, which promotes optimization and increased efficiency of government adminis tration. In 1980's, with the emergence of global approaches to admin istration where a special accent was made on humanitarian development, such decentralizati on came into the foreground.

In democratic states, separation of powers, competences and responsibilities among central, regional and local levels became one of the key trends of decentralization. Such decentralization can be defined as delegation of responsibili ty for planning, management and usage of resources from the central government to lower levels of administration. There are three types of this decentralization: political, administrative, and fiscal, and four forms: devolution, deconcentration, delegation and divestment.

In a federative state, decentralization is obligatory and takes form of power separation between the center and the regions based of the federalism principle. The latter presupposes a constitutionally laid down legal status of the regions, the extent of their rights, the manner of their interaction with the federation and among themselves, and the specific character of separation of competences, including a list of those competences, among the federal and regional authorities. Of course, normative, legal, structural, and institutional structures of different states differ according to their historical, cultural, geographic, etc. conditions. Still, the principle of nonintervention of federal government into the processes of formation and activity of regional powers is a universally acknowledged political and legal basis for 
actualization and observance of federalism and for an efficient separation of powers between the federal and regional levels. This principle may only be broken in extraordinary situations according to the subsidiary responsibility of the reg ions before the center.

Local self-government plays a very special role in decentralization. On the one hand, local self-government is a form of democracy based on self-organization and decision -making on the part of the local community, be it directly or through agencies it creates, in the wide field of its sustenance. On the other hand, local self-govern ment is a special kind of power that is not related to any branch or level of state power. It is one of the oldest institutions of democracy, one that allows citizens to protect their rights and to participate in social affairs. There are different and usually unique forms of the local government, since in order to be effic ient they have to correspond to local his torical and cultural traditions. Local self-government is an important link between the society and authorities, between social self-organization and dictatorial regulation of social relations by the government.

Socially, law-governed state is based on civil society, whose first and foremost feature and basic social value cons ist in sovereignty of the individual, of human rights and freedoms. Every individual, at that, may have their own moral values according to their worldviews and convictions.

Civil society performs the indispensable for a democratic and law-governed state function of social self-regulation and control of the state power's interventions into such relations that otherwise can be regulated without government institutions. Civil society is a horizontally organized social activity based on free and creative activities of individuals and groups.

Civil society is a complex social and political phenomenon regulated by law as well as by morality and traditions. Therefore, civil society is not a purely legalnotion and cannot be defined as some formal pattern or a finite number of specific subjects.

While ultimately separating the spheres of civil society and state as a political institution which integrates society, it is suggested that it is to the former that all formal and informal institutions, connections, and relations in a society, which are not predetermined by government activity, should be ascribed. According to this interpretation, we might include into civil society, as its constituting units, citizens (whose free personal development and private interests are based on civil rights, political freedoms, private property, and guarantees of pluralis m of ideas, views, opinions, and attitudes ) and their self-regulating independent communities (as constituting structures of the society). Such communities include family, public non-governmental associations and groups, informal communities, non-governmental subjects of economic, scientific, educational, cultural, and informati onal activities.

According to the approach proposed here, civil society includes all forms of social activity not caused by the governmental structures and representing the level of the society's self-organization. Thus understood, civil society defines the state of social connections and relations and serves as qualitative measure of the population's civil self-organization and as the main criterion of separation of functions between society and state in the social sphere[5].

The existence of alternative information sources is one of the key prerequisites for the formation of civil society and its institutional structuring and development as a democratic social environment. Freedom of communication and information exchange is important because interactions between individuals and groups, reliable information, and social and political activity of the citizens are basic energy sources for civil society.

In a democratic law-governed state, the interaction between civil society and government is built up on the assumption that civil society is a social foundation of state. Civil society not only forms a government according to the principle of democracy but also permanently controls the government institutions' activity, counteracting power abuses by both elected political elite and non-elected government bureaucracy. Civil society itself sets minimally sufficient political limits on government participation in social relations regulation, defines the government competences in social regulation, and grants the government necessary rights and responsibilities.

\subsection{Social State}

The modern democratic world order is based on the assumption that all people are born free and equal in their rights and dignity, as set forth by article 1 of the Universal Declaration of Human Rights. However, different people have very different possibilities for the realization of their rights and dignities due to circumstances of both their births and their lives, which can change during the person's life. Nature (in the widest sense of the notion) does not give people equal intellectual and physical abilities. Initial economic and social conditions differ and depend on every individual's personal and family history. Every person's life is influenced by natural, anthropogenic, social, and economic factors and cataclysms which can radically change their physical, social, and economic conditions and which may happen due to reasons beyond a person's control as well as due to their personal circumstances. Moreover, what is vitally important and utterly painful, it also impedes their social rights or sometimes even makes it just impossible for them to enjoy adequate life conditions without external support. Hence one of the burning social and political problems - that of social justice, which is always present in every democratic state's political agenda.

It is worth noticing that the rather popular point of view professing the fundamental or even antagonistic contradicti ons between individual freedom and social justice seems untenable. It is a purposefully constructed political mythologem aimed at disparagement of the liberal values and not an objective political reality. Such a mythologem is used both by left politicians dreaming of a utopia of total equality as the supreme form of social justice and by right politicians propagating social Darwin ism as an uncondition 
al and unambiguous extension onto the human society of the law of natural selection and struggle for existence found in the wild nature.

Within the framework of postindustrial development, social state is a state aimed at a practical harmonizing of individual rights and social justice in everyday life. The principal task of such a state is to provide every citizen with governmental guarantees of approximately equal opportunit ies for self-realization. Social state should also guarantee every citizen minimally adequate life conditions and sufficient level of social security. Social security here means protection fro m natural, anthropogenic, social, and economic changes and cataclysms as well as the possibility to participate in governance of state and society regardless of people's material conditions and social status. It should be stressed that the latter task is of no less importance for the social state than the former two, since that possibility is an integral part of social justice in its modern political and legal interpretation.

Modern social problems are caused not only by globalization and demographic situation but also by the inability of the traditional redistribution mechanism to adapt to the new challenges or to adequately solve the problems. It mainly concerns the princip le of social solidarity that had successfully helped solve social problems in the situation of essential property differentiation but has little capacity and is being rejected by a significant sector of the society in the situation of social homogeneity and middle class domination. Social state as exclusively redistribution mechanis m destructively effects not only economy and entrepreneurial milieu but also social well-being. Active and all-embracing governmental paternalism radically reduces people's inclination not only for risk but also for independent decision-making that requires their own investments.[6].

Excessive social encu mbrance of the able-bodied citizens and redundant governmental paternalism, even with the social consensus concerning them, lead to loss of quality in the country's human capital. The most active and capable citizens begin to leave the country. Even such socially successful nations as Norway and Sweden now face this problem.

In order to minimize the probability of such problems and situations, governmental social support should be as targeted as possible and be provided only to those who is really in need, who is unable, because of objective reasons beyond their control, to provide for themselves minimally adequate life conditions. Targeted social support promotes more rational and efficient spending of the allocated material resources, which are always limited.

The formation of a favorable social environment for self-realization and creative development and the raising of the level of social security are common aims for both government and society. In the social state, this aim is achieved by uniting efforts and resources of the government, charitable, volunteer and other social organizations, and the non-governmental sector of the economy based on their partnership and mutually beneficial co-operation.

In a social state, the principle of its social responsibility becomes the main principle of governmental activity. The governmental principle of social responsibility means that the government commits itself to guaranteeing and providing for approximately equal opportunities for all people's self-realization; minimally adequate life conditions for each citizen; an adequate level of social security seen as protection against natural, anthropogenic, social, and economic changes and cataclysms; possibility for all to participate in governance of state and society regardless of their material conditions and social status. The government is also supposed to carry out such a way of state regulation that aims at the creation of stimuli and favorable conditions for socially oriented activit ies of the non-government sector.

A socially responsible government provides social guarantees not through depersonalized governmental paternalism, which usually causes social parasitis $m$ and promotes marg inal asocial groups, but through a purposeful governmental policy in the social sphere. Such a policy gives priority to creating the best conditions for personal development as the most effective way to ease out the entire range of social problems. Social support is targeted to the least privileged social groups and citizens through a social consensus in such a way of redistributing government resources as is deemed necessary for providing such support.

\subsection{Secular State}

In the judicial context, secular state is such an organization of state order that is specifically aimed at observance and protection of freedom of thought, conscience, and religion as well as other convictions, including non-religious ones, as stated in a binding form by article 18 of the General Pact of Civil and Political Rights, i.e. at an actualization of the principle of state's nonintervention and tolerance towards different religious and non-religious worldviews and convictions.

Generally speaking, the term "secular" refers to a constitutional and legal characteristic of a state which means the separation of Church and state and the demarcation of their scopes of activity. Here "Church" is to be understood as any association existing on a religious basis, and in this interpretation, proposed by E. Durkheim, "In h istory we do not find religion without Church".[7].

Interrelations between secular state and religion are based mainly on the fact that no particular religion may be established as a state religion or, what is especially significant, as an obligatory one.

On the institutional level, a state can be characterized as secular if it has neither constitutionally or otherwise legally established institutions by means of which clergy might influence governance, nor government offices specially designated for being filled by clergy. The state, in turn, does not delegate any governmental functions to the religious communities. The constitutions of secular states declare religious communities as separated from state, autonomous 
and free entities having equal rights. The government does not intervene in the relig ious communities' activities as long as the latter are legal. Interactions between the secular state and religious communities are based on the principles of separation of scopes and mutual non-intervention and is regulated by laws or agreements. More often than not, such contractual relations are established with a religion which is historically dominating and, as a rule, supranational but never established as a state one.

Institutional separation of religious communities from state is a necessary but not sufficient condition for liberation not just governmental but the entire political activity from religion's control and influence. For such liberation on the procedural level, it is necessary to restrict the participation of religious associations and especially the clergy in politics. Such restrictions, it seems, must mainly concern a prohibition on material, organizational, and propagandist support of political parties by religious associations and clergy, including a prohibition on the formation of parties on a political principle. Any restrictions on the believers' political rights are inadmissible for common people but possible for professional clergy.

In a secular state not only relig ious communities or clergy must not participate in political life but the political figures also must have no right to use relig ion for political purposes.

Political use of religion means public participation of the clergy in officialgovern mental and political events as wellas participation in the religious ceremonies and rituals of the officials and politicians in their official status. Certainly all state officers, politicians and state officials of all ranks have the right for religious convictions and preferences but it should remain their private affair and must not be demonstrated in public.

Public demonstration by the officials, especially those of the highest rank, of their adherence to a particular religion, especially the historically dominating one, is just a populist method of power preservation through using protective functions and authoritarian tendency that are inherent to a degree in all religions. The protective function of religions is their capacity to resist changes and direct its authority to the preservation of political and social status quo. Authoritarian tendency in religion is concerned with an acknowledgement of an external power which controls a person's life and demands obedience and worship not because of moral qualities of the deity, not out of love and justice but because of the deity's dominance over a person[8]. Such political method is typical for authoritarian political regimes but is destructive for the constitutional principle of state's secularity as it leads to clericalis $\mathrm{m}$ in government processes and provokes in mass consciousness negative attitudes towards citizens devoted to other religions and beliefs and even not religious worldviews.

Such public demonstration of the religious preferences by high rank officials, their participation in religious ceremonies and rituals in their official status promotes not real faith but rather a mass fashion for religion with an apparent political hue, which primarily attracts state bureaucrats of all ranks. Th is seems a profanation destructive for any religion and violating religious feelings of sincere and committed believers

In a secularstate, as far as public policy and the permanent open dialogue between state and society are concerned[9], religious associations should participate in this objectively necessary dialogue on princip les different from other public associations. The reason for this is that only religious associations are constitutionally separated from the state and have no right to participate in governance, even by way of official lobbyism.

In a secular state, along with the rejection of a state or obligatory religion, any procedural possibility for the clergy to influence political and governmental activity directly or indirectly should be excluded and any use of religion for political purposes, forbidden.

While assessing the relation between law and religion in a law-governed state one should proceed from the key role that in a law-governed state is played by the most important institution of modern law, the institution of human rights and interactions between individual and religion in the social sphere.

Interrelations between the human rights institution and religion as a social phenomenon have a specific character in that every religion is socially inclusive, i.e. has the capacity and aspiration to penetrate social sphere by means of religious norms and rules established for individual and group behavior both in relations among the people and those between the people and the state. Different religions at different times have had different degrees of correlation and separation of the spiritual and the mundane (i.e. social) and, as a consequence, of the depth and character of regulative penetration into the social sphere.

Every contemporary religion, in order to strengthen its own and its clergy's spiritual influence, seeks to regulate everyday life by way of religious norms and rules, i.e. it aspires not only to spiritual power but also to the role of a regulator of relations in the social sphere. Moreover, out of the vast multitude of the religions, each one presumes itself the only true and universal one and therefore none of them inherently can serve as a social regulator significant for all.

The role and place of religion in the modern world and secular state is determined by its being one of the most influential and significant phenomena as far as worldview is concerned. Yet today, people's convictions and worldviews are as diverse and many-faced as humanity itself. The worldview that defines the individual's values, moral and ethic principles, and notions of good and evil may or may not be religious; e.g. atheism or agnosticism are fairly widespread today. This sphere of being, of spiritual and intellectual activity has competitive and largely uncomprom ising character. The secularity of state objectively helps widen and strengthen competitiveness among different worldviews.

All religions, therefore, should, it seems, to concentrate their activity mainly on spiritual and intellectual spheres using different forms and methods of religious education and 
persuasion without any enforcement. Besides, the humanistic tendency should become the main one in the social role of religion, which has been changing during the historical process of human development. The humanistic tendency in religion proclaims the unconditional worth iness of a human being as a God's creature, stimulates possibilities for self-realization, orients a pers on to develop their mind to understanding themselves, their attitudes toward others, and their place in the universe, develops the ability to love others like oneself, and the feeling of unity of all living creatures.[8].

In a secular state, every religion can assume the role of a local social regulator within the relig ious community formed on its base. Yet, that can only be the case if all members of such a community are ready voluntarily and with no enforcement to restrain their universal rights and freedoms in order to follow in their everyday lives the prescriptions, rules, and norms of the religion they adhere to. Still, any other citizen's rights and freedoms may by no means be violated.

\section{Conclusions}

The model ofdemocrat ic state in which it is law-governed, social and secular is becoming the modern world's most dominant. It's not only realized on a practical level in truly democratic states — though not always fully or ideally but even on a constitutional level in states which today are far from democratic political ideals.

\section{REFERENCES}

[1] Dahl, Robert A. On Democracy. Yale University Press, 1998.

[2] Nisnevich Yuliy A. The Modern Methodes of Political Research // Bulletin of RUDN, political science series, №2, pp.5-16, 2011.

[3] Nisnevich, Yuliy A. Law and politics. Moscow, An open Russia, 2005

[4] Hayek, Friedrich. The road to serfdom. University of Chicago Press, 1994.

[5] Solovyev, Alexander I. Political science: political theory, political technologies. Moscow, Aspect Press, 2008.

[6] Gutnik, Vladimir P. Germany: successes and failures of social market economy / In Market democracy in action. Modern political and economic organization of the developed countries. Moscow, Institute for the economics of the transition period, 2005.

[7] Durkheim, Emile. The Elementary Forms of Religious Life. Oxford University Press, 2001.

[8] Radugin, Aleksey A. Introduction into the religious science: theory, history and modern religions. Moscow, Centre, 2004.

[9] Nisnevich, Yuliy A. Informational and communicational stabilizing of the political system // Bulletin of RUDN, political science series, №1 (6), pp. 68-70, 2006+. 